\title{
Formalism and the Appearance of Nature
}

\section{Citation}

Moran, Richard. 2018. Formalism and the Appearance of Nature. Michael Fried and Philosophy: Modernism, Intention, and Theatricality, ed. Mathew Abbott. New York: Routledge.

\section{Permanent link}

http://nrs.harvard.edu/urn-3:HUL.InstRepos:41467541

\section{Terms of Use}

This article was downloaded from Harvard University's DASH repository, and is made available under the terms and conditions applicable to Open Access Policy Articles, as set forth at http:// nrs.harvard.edu/urn-3:HUL.InstRepos:dash.current.terms-of-use\#OAP

\section{Share Your Story}

The Harvard community has made this article openly available.

Please share how this access benefits you. Submit a story.

Accessibility 
Formalism and the Appearance of Nature

\begin{abstract}
Richard Moran
In Michael Fried and Philosophy: Modernism, Intention, and Theatricality, edited by Matthew
\end{abstract} Abbott (Routledge, 2017)

In aesthetic discussion, the term 'formalism' has a role that is at least as much polemical as theoretical. Something called 'formalism' has had its defenders for a long time, but I think it's fair to say that more often it serves as an accusation to be deflected, the very word 'form' always seeming to have the inflection of the 'mere' trailing before it as a diminution. This is not Roger Fry's or Michael Fried's usage, of course, but the polemical context of the term registers its presence in their writings in various ways.

I don't know that Fried himself has ever explicitly defended something called 'formalism' in art or criticism, and it certainly seems an inapt term to characterize his brilliant readings of French painting since his first book Absorption and Theatricality. But the appearance of that book follows by several years Fried's deeply influential writings on contemporary American painting in the wake of Jackson Pollock. In that context the polemical function of the term 'formalism' is inescapable, and the fires lit by those battles have not died down today. ${ }^{1}$ So although I was surprised and intrigued to learn that "Roger Fry's Formalism"

\footnotetext{
1 Indeed, in his "Introduction to My Art Criticism," Fried expresses reservations about his invocation of "formal
} criticism" in his earliest art criticism, particularly in "Three American Painters." 
would be the title of Fried's Tanner Lecture, ${ }^{2}$ the connection seemed a natural one. What I didn't expect was that this lecture would be an opportunity to examine the relations between 'formalism,' of Fry's variety anyway, and the other major term of art at play here, that of 'theatricality' itself. For although both terms have been active in Fried's writings since the publication of his essay "Art and Objecthood" back in 1967, I'm not aware of any previous occasion where Fried has used them to illuminate and question each other as in this lecture. On Fried's reading, Fry belongs to the tradition of anti-theatrical criticism, a tradition which gains its first great expression in the writings of Denis Diderot, and his formalism develops as a progressive attempt to give expression and defense to the underpinnings of this sensibility. Formalism of any kind is defined by what it excludes, and early in his essay Fried makes clear how, on his reading, this works in Fry's criticism: "The counter to form, form's 'other,' is not primarily subject matter, content, illustration, literariness, or representation as such - though at times he speaks of all of these in this connection - but drama, that is dramatic expression." ${ }^{3}$

${ }^{2}$ I will be referring to the text of "Roger Fry's Formalism," Fried's original lecture delivered on November 2 and 3, 2001 at the University of Michigan, and which has since been published in modified form in Another Light (195-223). The lecture is available at the University of Utah's library of The Tanner Lectures on Human Values at http://tannerlectures.utah.edu/lecture-library.php. Fried's text is available at http://tannerlectures.utah.edu/_documents/a-to-z/f/fried_2001.pdf (accessed 17/04/2017).

3 Fried, “Roger Fry's Formalism," 7. 
It's because I find Fried's orientation here so convincing that in my remarks here I want to interrogate it further, particularly in relation to difficulties the anti-theatrical tradition has in making out the terms of the autonomy of the artwork, a concept that is central to the formalist project. Having thus invoked the concepts of autonomy and form, it will surprise no one that I mean to talk about Kant. Perhaps more surprising is the pervasiveness of anti-theatrical themes in Kant's own writings on philosophical aesthetics.

But first let me say something about the concept of 'theater' in question here. In his 1980 book Absorption and Theatricality, Fried charts a tradition of painting and criticism in Eighteenth Century France which sought to defeat what was seen as the inherently theatrical nature of painting. Paintings are made to be beheld, but within the convention that the beholder is witnessing a (depicted) scene, the implicit awareness of being beheld, on the part of the (depicted) figures in a painting, threatened the depiction with what Diderot characterized as the merely theatrical in human expression: that is, the false and the mannered. Painting will be most successful, and our conviction in the genuineness and reality of the depiction will be all the greater, when it manages somehow to defeat what he saw as the inherent theatricality of the medium. One prominent strategy for doing so, which Diderot championed, was the depiction of figures in various states of emotional absorption, either by being in the grip of some powerful emotion or by having their attention wholly occupied with some task, and whose obliviousness to their surroundings (within the painting) figuratively includes their unawareness of being beheld by an implied beholder outside the painting, and thus seeks to establish what Fried calls "the supreme fiction" (AT 103) of the absence of the beholder before 
the canvas. The defeat of theatricality aims at once at the sense of the reality of the scene, or the sense of the genuineness of a particular human expression, and the beholder's emotional participation in the scene (paradoxically, by being placed outside its world).

However, given the "primordial convention" (AT 93) that paintings are indeed made to be beheld, and the fact that it can never be more than a "supreme fiction" that the beholder is absent, we should expect that Diderot's solution to the problems of theatricality would be an unstable one. Its instabilities relate in various complex ways to the internal requirements of painting itself. In the 'absorptive' tradition of painting, the conviction accorded to overt displays of passion is purchased at the eventual cost of an enhanced sense of the artificiality of the entire contrivance of painting. For, as critic or beholder, one cannot reflect on (let alone, praise) the impression of genuineness and reality in the expression without thereby recognizing this impression as something deliberately and skillfully produced for our eyes, for the very impression it makes. But then this recognition on the part of the critic reveals the inherent theatricality of the whole production, and hence subverts the sense of reality in the depiction. At this point some other artistic solution must be found.

What is meant by 'theater' in this context should not be confused with what we understand today as the 'fourth wall illusionism' of naturalistic drama (and was not so in Diderot's world). For indeed, the illusion of the fourth wall at the edge of the stage is precisely the embodiment of the "supreme fiction" that the beholder is not present, that we in the audience are peering into and overhearing another world that doesn't not register 
consciousness of our presence. Closer to the meaning of the 'theatrical' in the critical context of Diderot and others is the situation of dramatic oratory or rhetoric, the heightened address of the audience and display of emotion before them, in order to secure the self-delight of moving them, dazzling them, re-directing their desire. The orator is an actor as well, but his art involves a facing of the audience, and a direct appeal to them, rather than real or feigned unconsciousness of their presence. And that is because his art has its end in something outside the performance itself, in his self-conscious concern with its effect on his audience. In this sense the figure of the dramatic orator is the embodiment of something essentially unartistic for critics in the anti-theatrical tradition. Here we may recall Fry's complaint of the figures in a canvas by Andrea del Sarto that "[o]ne feels... that they are arranged entirely with a view to the effect to be produced on the spectator," ${ }^{4}$ or in contrast his praise for El Greco's "complete indifference to what effect the right expression might have on the public." ${ }^{5}$

And yet, of course, if it is in the nature of painting to be produced in order to be beheld, what can there be to object to in the painter's concern with "the effect to be produced on the spectator"? The painting is something addressed to a beholder, so attention to this ought not to seem per se a violation of the artist's or work's autonomy. Naturally there are familiar

${ }^{4}$ Roger Fry, “An Essay in Aesthetics," in Vision and Design, ed. J. B. Bullen (Oxford: 1981) (, 17.

5 Fry, “An Essay in Aesthetics," 8. 
failings and corruptions of the artist's imagined relation to his public, and these go by various names. But likewise there are corruptions in the artist's imagined relation to the work itself, considered apart from its relation to an audience. In neither case is the cure to be found in the obviation of that relation itself. How, then, can unconsciousness of an audience, or rather pretended unconsciousness of their presence, come to seem a model for authenticity in artistic production?

The opposition that guides the practice of Fry's anti-theatrical criticism is given one classic formulation in the famous contrast between 'poetry' and 'eloquence' in John Stuart Mill's 1833 essay "What is Poetry?", which Fry must have been familiar with, but which I am unaware of him citing. Here the term "poetry" stands for Art in general, and "eloquence" is the name for the fall from this condition, the ever-present possibility of its decline into something other:

Poetry and eloquence are both alike the expression or utterance of feeling. But if we may be excused the antithesis, we should say that eloquence is heard, poetry is overheard. Eloquence supposes an audience; the peculiarity of poetry appears to us to lie in the poet's utter unconsciousness of a listener... All poetry is of the nature of soliloquy... But no trace of consciousness that any eyes are upon us must be visible in the work itself. The actor knows that there is an audience present; but if he acts as though he knew it, he acts ill... But when he turns round and addresses himself to another person; when the act of utterance is not itself 
the end, but a means to an end, - viz. by the feelings he himself expresses, to work upon the feelings, or upon the belief, or the will, of another, - when the expression of his emotions, or of his thoughts tinged by his emotions, is tinged also by that purpose, by that desire of making an impression upon another mind, then it ceases to be poetry, and becomes eloquence. ${ }^{6}$

Among other things, this passage registers a deep ambivalence about the power of poetry, and the very idea of submitting oneself to this power, an ambivalence which threatens to spread to a generalized anxiety about the influence of another person on one's feelings or belief at all. Within the terms given here, it is difficult even to describe the situation of direct artistic address to an audience which doesn't collapse into some form of the intent to pander to or manipulate them; or in Mill's deliberately aggressive terms "to work upon the feelings, or upon the belief, or the will, of another." It is not that every utterance which is directed upon the feelings of another can be rightly described as seeking to "work upon" those feelings, but in Mill's essay the naturalness and spontaneity of poetic utterance is conceived as precluding any consciousness of such an aim. This cannot be a stable solution, even in Mill's own terms. He tells us that the poet's utterance is not made with "the desire of making an impression upon another mind," and yet it is clear from elsewhere in the essay that "making an impression upon another mind" is quite an important criterion of value in poetry. As we might expect, poetry

\footnotetext{
${ }^{6}$ John Stuart Mill, "What is Poetry?" in Literary Essays, ed. Edward Alexander (Indianapolis: Bobbs-Merrill 1967), 56-7.
} 
that fails utterly to do this, fails as poetry.

In the anti-theatrical tradition, how does "making an impression" as such get cast in terms of the exhaustive options of either vain self-display or emotional manipulation? This question applies equally to Fry, for whom the artist must indeed address our emotions, and yet must somehow appear not to do so, or do so without "a view to the effect to be produced on the spectator"; or he must somehow make a difference to what we feel while exhibiting a "complete indifference to what effect the right expression might have on the public." And yet Fry is equally insistent that the artist is in the business of making a difference to what his audience feels, that he aims at making a particular impression, and indeed that the experience of art is characterized by the audience's recognition of this aim:

It may be objected that many things in nature, such as flowers, possess these two qualities of order and variety in a high degree, and these objects do undoubtedly stimulate and satisfy that clear disinterested contemplation which is characteristic of the aesthetic attitude. But in our reaction to a work of art there is something more - there is the consciousness of purpose, the consciousness of a peculiar relation of sympathy with the man who made this thing in order to arouse precisely the sensations we experience. And this recognition of purpose, I believe, is an essential part of the aesthetic judgment 
proper. $^{7}$

Hence not only does Fry insist that the artist "made this thing in order to arouse precisely the sensations we experience," and that "sensations are so arranged that they arouse in us deep emotions," ${ }^{8}$ but he equally insists that our recognition of this purpose is essential to the aesthetic judgment proper:

When the artist passes from pure sensations to emotions aroused by means of sensations, he uses natural forms which, in themselves, are calculated to move our emotions, and he presents these in such a manner that the forms themselves generate in us emotional states, based upon the fundamental necessities of our physical and physiological nature. The artist's attitude to natural form is, therefore, infinitely various according to the emotions he wishes to arouse." ${ }^{9}$

Various relations between formalism and the anti-theatrical begin to emerge from these passages. The critique of the 'theatrical' artist takes a number of different forms here: moral, psychological, political, and aesthetic. This figure of the artist is active and deliberate in his ${ }^{7}$ Fry, "An Essay in Aesthetics," 21 (emphasis added).

${ }^{8}$ Fry, "An Essay in Aesthetics," 26

${ }^{9}$ Fry, “An Essay in Aesthetics," 26 (emphasis added) 
aims, which seems to construe his audience as something passive to be worked upon. Insofar as his activity is directed upon the "feelings, or upon the belief, or the will, of another," it will seem that he is either aiming to gratify his audience (in which case he is accused of pandering and flattering), or he is seeking to dazzle and impress this audience (in which case he is accused of the vanity of self-display). And even if he has some nobler purpose in mind in seeking to make an impression on another mind, he will be then be found guilty of didacticism, of reducing his poetry, his art, to a mere vehicle of some idea, some Philosophy. In all these cases, poetic or artistic effectiveness becomes indistinguishable from some form of manipulation, so long as the artist stands in a conscious, deliberate relation to such effectiveness. Even when the audience itself stands in no danger of malign influence here, there remains what is perhaps the most damning (or hurtful) criticism of all, which is that strictly as a matter of taste there is something unseemly in the direct appeal to the audience, in overtly soliciting their response, courting their approval. Once again the critique centers on the overtly active role of this artistic figure, not because his activity threatens harm, but because of what is abject or off-putting in his overt soliciting of our attention and approval.

As it happens, virtually every element of this critique can be found within the brief lines of one of Keats's more famous letters, which is itself a central document of the anti-theatrical tradition:

It may be said that we ought to read our Contemporaries. That Wordsworth \&c should have their due from us. But for the sake of a few fine imaginative or 
domestic passages, are we to be bullied into a certain Philosophy engendered in the whims of an Egotist - Every man has his speculations, but every man does not brood and peacock over them until he makes a false coinage and deceives himself... We hate poetry that has a palpable design upon us - and if we do not agree, seems to put its hand in its breeches pocket. Poetry should be great \& unobtrusive, a thing which enters into one's soul, and does not startle it or amaze it with itself but with its subject - How beautiful are the retired flowers! How would they lose their beauty were they to throng into the highway crying out 'Admire me I am a violet! Dote upon me I am a primrose!' Modern poets differ from the Elizabethans in this. ${ }^{10}$

In spirit this is not too far from an outburst of Diderot's which Fried quotes in his first book, by way of compactly illustrating the relations of absorption and the contrary terms of self-consciousness, theatricality, self-display, and mannerism:

It is rare that a being who is not totally engrossed in his action is not mannered.

${ }^{10}$ John Keats, Letter to J. H. Reynolds (Feb 3, 1818), in Selected Letters of John Keats, ed. Grant F. Scott (Cambridge: Harvard University Press, 2002) 86-87. 
Every personage who seems to tell you: "Look how well I cry, how well I become angry, how well I implore," is false and mannered. (AT 99)

And, as we've seen, in the words of both Keats and Diderot, as well as other figures in the anti-theatrical tradition such as Mill and Fry himself, the self-conscious display of itself on the part of the artwork, is read not simply as mannered or vain, but also in terms of some ulterior motive, some base instrumentality in the artwork's relation to us. Keats puts it in terms of "poetry that has a palpable design upon us," and Fried picks up on the specially inflected senses of the words 'design' and 'having designs' in Fry's language (beginning with "Vision and Design"): [U]nconsciousness lines up with antitheatricality, not having a design on an audience." $^{11}$

Part of what I think we can hear in such passages is the anti-theatrical critic's proper anxiety over the question of how it is that an artist gains the right to the attention and response of an audience at all. In the encounter with the work of art we are indeed solicited, appealed to, and a kind of responsiveness is asked of us that we don't normally feel simply obliged to provide even to the perfectly real people we encounter in our daily lives. Outside of aesthetic contexts, courting or soliciting some emotional response from a person is not something done for free, but presumes some prior relationship of trust, shared history, and mattering to each

11 Fried, "Roger Fry's Formalism," 21 (see also RF 210). 
other. Without such a context, such an appeal is normally not only an affront of sorts, like being buttonholed in the street, but fails even to make ordinary sense. Why should it be different in the case of the artist? How can he simply show up, come before us with his "expression or utterance of feeling" and think that he has earned the right to ask us to respond?

But this anxiety, whatever it ultimately is, has to spread much more generally. That is, the suspicion of this or that aim or design on the part of the artwork, this or that instrumentality, is destined to evolve into or reveal itself as a quite general rejection of any 'external aim' or objective to the work of art. This is the formalist moment in the anti-theatrical dialectic. It is this thought which gives us the very distinctions between something internal and something merely external to the enterprise, as well as the ideas of autonomy, existing for-it's-own-sake, and self-sufficiency. For Fry as well as for Kant 'form' itself is the name for what remains after we have abstracted from whatever contingent external relations and aims the artwork may have attached to it, and revealed its internal necessities. 'Form' is the artwork nobly refusing to serve any master but itself, and too proud and self-sufficient to need to solicit the admiration or tears of an audience. The thought is that if we speak of art as determined by any aim or purpose at all, then art is being reduced to something merely instrumental, a means to an end, and hence in principle a replaceable means.

In Fried's lecture, we can see Fry's rejection of theatrical display and appeal as taking him further into a formalist conception of the painting, laid out in the markedly Kantian terms of autonomy, necessity, internal relations, unity, and law. For instance, Fried describes Fry's 
re-casting of the rhetorical art of the High Renaissance as involving "an appeal to qualities of form or design, which being closed in on themselves, in that sense wholly internal to the work in question, rather than addressed to a beholder, provided an antitheatrical 'core' that far outweighed in significance all other aspects of the work."12 And later Fried invokes a further range of Kantian concepts in saying that "Fry imagines the finished painting to be wholly autonomous with respect to the real world."13

One strain in the idea of 'autonomy' is in the idea of independence. In the case of painting we can identify three dimensions of independence. As with the work of art generally, a painting is different from other artifacts such as instruments, clothes, or furniture in that it is not created to serve any end that precedes it. The meaning and value of a work of art is not determined by how well it serves any end, whether practical, moral, or religious. Secondly, in the case of painting, the modernist period is characterized by various struggles of emancipation from the dependence on the visual world, from the idea of pictorial representation itself. The meaning or value of the painting is explicitly and self-consciously presented as independent of visual appearance and its 'faithful' depiction, and the visual world is conceived of as 'external' to the painting, as much as any instrumental aim is to the work of art as such. And finally, the

${ }^{12}$ Fried, "Roger Fry’s Formalism," 16.

13 Fried, “Roger Fry’s Formalism,” 25. 
work of art is independent of the audience itself, whether the solicitation of the audience, the pleasure, the taste, or perhaps even the comprehension of the audience. Here in a different but related register, the 'audience' is figured as 'external' to the work of art and for the artist to turn his attention there and seek its applause (or understanding?) can be no less a corruption than would be to treat a work of art as a tool in the service of some external aim. The painting as art is independent of any instrumental aim (rejection of art as either moralistic or mere entertainment), independent of the representation of the visual world as a criterion of value, and independent of the taste of the audience, or the need to gratify its needs or gain its applause.

The 'autonomy' of the work of art, like the 'autonomy' of the Kantian moral agent, does not merely imply that the work or art or the person is 'independent' with respect to something else, whether an audience or other people generally. For what is being rejected in the declarations of independence above is a kind of normative dependence or subordination. A practical aim, faithful representation, or the responses of an audience are all denied as criteria of success for the work of art; the success or failure of a work of art is not determined by anything 'outside' the work of art itself (which concept is thus being re-defined, as separate from the world of crafts) but by its own 'inner necessities.' As with the characterization of the Kantian moral agent, 'autonomy' is first of all the notion of 'self-rule,' and the meaning of 'independence' in these other contexts will be dependent on the understanding of the specific conditions of self-rule. Success or failure, goodness or badness, is determined by nothing that is not internal to the concept in question, whether that be good action, moral personhood, or the 
work of art. It is determined by no laws that is has not given itself. In his address to the British Psychological Society in 1924, "The Artist and Psychoanalysis," Fry is chiefly concerned to reject a notion of the artwork as having its meaning outside itself, that is, in some symbolism, and insists on the work of art as "completely self-consistent, self-supporting, and self-contained."14 Both symbolism and dramatic appeal count as external dependencies which the work of art may partake of but are impurities obscuring what the artwork is in and of itself: "None the less in proportion as an artist is pure he is opposed to all symbolism."15 Fried argues persuasively that "Fry's notion of pictorial unity is itself essentially anti-theatrical" ${ }^{16}$; what this shows is that 'theater' and its appeal to an audience functions as the name for external dependencies of the artwork quite generally, 'unity' being now a figure for the completeness and self-sufficiency of the work of art. Hence the anti-theatrical critic, in his rejection of any heteronomous aims for the artwork, sees his work as the paring away of such external dependencies so as to reveal the operation of a unifying law: pictorial unity, Fry tells us, is "a unity where all the parts are bound to each other inevitably," ${ }^{17}$ and "this perception of unity and necessity is very like the

${ }^{14}$ Roger Fry, "The Artist and Psychoanalysis," in A Roger Fry Reader, ed. Christopher Reed (Chicago: University of Chicago, 1996), 362.

${ }^{15}$ Fry, "The Artist and Psychoanalysis," 362.

${ }^{16}$ Fried, "Roger Fry's Formalism,” 14

${ }^{17}$ Quoted in Fried, 'Roger Fry's Formalism', 18 
perception and comprehension of a natural law."18

The insistence on unconsciousness of any deliberate aim on the part of the artwork or performer is itself an important stage in Kant's developing formalist argument, and grows out of an anti-theatrical animus he inherits from Rousseau. Throughout The Critique of Judgement Kant notoriously privileges both the beautiful in Nature over the beautiful in Art, and the 'naïve' expression over any deliberate expression with an intent to convey something. In both cases the active intervention of the human will is pictured as a basically corrupting or falsifying barrier between us and something genuine. Passivity or unconsciousness in expression has a probative power necessarily lacking in any deliberate self-display. Given its status as a human artifact with an internal relation to a possible audience, the work of art is under constant threat of revealing itself as "intentionally aimed at our liking,"19 and therefore both flattering and falsifying. The language of the anti-theatrical is unmistakable in passages like the following:

But in art a product is called mannered only if the way the artist conveys his idea aims at singularity and is not adequate to the idea. Whatever is ostentatious, precious, stilted, and affected, with the sole aim of differing from the ordinary

${ }^{18}$ Quoted in Fried, 'Roger Fry's Formalism', 18

${ }^{19}$ Immanuel Kant, The Critique of Judgment, trans. Werner Pluhar (Indianapolis / Cambridge: Hackett, 1987), 168; Ak, 301. 
(but without spirit), resembles the behavior of those who, as we say, listen to themselves talking, or who stand and walk as if they were on a stage so as to be gaped at, behavior that always betrays a bungler. ${ }^{20}$

The solution to this dilemma is a radical one: if art is to have a legitimate claim on our attention it must not appear to solicit our response at all; and thus in a culminating moment of the Analytic of the Beautiful the beautiful in art is defined by excluding the appearance of human intention altogether, and $a$ fortiori excluding the appearance of soliciting the attention of an audience. The heading of this chapter states that "Fine Art is an Art Insofar as it Seems at the Same Time to be Nature." Kant writes: "Therefore even though the purposiveness in a product of fine art is intentional, it must still not seem intentional; i.e., fine art must have the look of nature even though we are conscious of it as art." "Nature" here is thus the figure both of the natural and unconscious in expression, that which is without any designs upon us, and of the unified and self-sufficient realm governed by necessities internal to itself. As with Mill, the audience may be assured that its thought and emotion are not being worked upon because the pretense is that they are not being addressed at all.

The idea of the 'self-contained' is central to formalist motivations, and it bears

${ }^{20}$ Kant, The Critique of Judgment, 188; Ak. 319.

${ }^{21}$ Kant, The Critique of Judgment, 174; Ak. 307. 
an uneasy relation to the critical imperative to purge the description of one's experience of any dependency on what, properly speaking, lies 'outside' the artwork. In Fry it gives rise to an idea of a kind of chemical analysis applied to the experience of painting: "It seems to that this attempt to isolate the elusive element of the pure aesthetic reaction from the compounds in which it occurs has been the most important advance of modern times in practical aesthetic." ${ }^{22}$

We have seen the idea of the work of art or the idea of the beautiful arrived at by a process of subtraction from various 'external' dependencies which characterize our practical lives and the humanly produced artifacts which serve them. This construction gives rise to a corresponding set of 'purifying' or 'subtractive' critical imperatives which oblige the beholder of a painting to insure that his response to the painting is determined solely by its 'internal' or properly aesthetic properties and is not influenced by what is properly seen as 'external' to the painting as work of art. Kant's formalist project in aesthetics is defined by a similar task of paring away a disparate set of motivations contributing to one's delight in some object before one can tell that this delight belongs to the aesthetic at all. The judgement of taste is indeed based on pleasure, but it is rendered independently of any desire for the object, any empirical interest in it, any concepts under which the object may fall (including that of goodness or perfection), and any belief in the actual existence of the object.

${ }^{22}$ Fry, "Retrospect", in Vision and Design (Oxford University Press, 1981), 209-10 (see Fried, “Roger Fry’s Formalism,” 12). 
And it is because of this commitment to purification that formalism seems to exist permanently as a utopia in art criticism, a place we have never arrived at, but can just barely keep in view; something announced as a correction of the ordinary contexts in which we experience and come to care about works of art, which is incurably messy and promiscuous in the actual influences and concerns which inform it. The trope of purity and contamination which defines the rhetoric of formalism insures that the triumph and reign of the formalist project must forever exist in the hereafter, something gestured at but never enacted, perhaps not even describable. For any purity is of course defined by what it excludes, and hence among other conceptual problems, the formalist critic must, in subjecting himself to proof of what has been excluded from his practice or his sensibility, involve himself in all the familiar logical problems of proving a negative: demonstrating somehow that the appeal of non-formal considerations, while undeniably pressing, played no role or were rendered inactive in his aesthetic response.

This is a difficulty which Kant, the father of formalism in both ethics and in aesthetics, saw more clearly in the case of moral motivation than he seems to have in the case of the response to beauty. If a morally admirable action is one undertaken solely from the motive of duty, and not out of any personal or sentimental inclinations we may have, then it may seem that for any action of another person or even of our own we are faced with the problem of demonstrating that respect for the moral law was in this case the sole operative motive for the person. And this, Kant sees, is something which cannot be demonstrated even to oneself in the first-person case, where one might think that facts of one's reason for action might be more 
immediately open to view:

One still cannot show with certainty in any example that the will is here determined merely through the law, without another incentive, although it seems to be so; for it is always possible that covert fear of disgrace, perhaps also obscure apprehension of other dangers, may have had an influence on the will. Who can prove by experience the nonexistence of a cause when all that experience teaches is that we do not perceive it? ${ }^{23}$

In the case of ethics we can take this as counsel against complacency in our moral assessments of ourselves and other people, since the conclusion seems to be that in principle we can never know the moral truth about our own action or that of others. And in the case of aesthetics we may take it to mean that the problems of identifying the properly aesthetic, which Fry wrestles with in terms of the analogy with chemical analysis, cannot be handed over to the experimental psychologist, as he suggests at the end of his 'Retrospect. ${ }^{24}$

But anti-theatricality and formalism share a deeper conflict within themselves,

${ }^{23}$ Kant, Groundwork of the Metaphysics of Morals, (trans. Mary Gregor, Cambridge 1997) 30, Ak. 419 Earlier he insists that "it is absolutely impossible by means of experience to make out with complete certainty a single case in which the maxim of an action otherwise in conformity with duty rested simply on moral grounds and the representation of one's duty." (19, Ak. 407)

${ }^{24}$ Fry, 'Retrospect', 210. 
stemming from their understanding of the task of abstracting the work of art from any external end it may find itself appealing to or in the service of, and returning it to the faithful pursuit of its own internal necessities. For unavoidably they find among these internal necessities the relation to an audience itself, which re-opens all the old questions of dependency on an end 'outside itself,' instrumentality and heteronomy. As with mathematics or morality itself, we can see the work of art as defined by its own internal necessities, by its own self-given laws. And the various failures or corruptions of the internal autonomy of the work of art, when it submits to laws or interests outside its own realm, takes many familiar forms. But the problem remains that, while all of these forms of failure can indeed be seen as compromises of aesthetic autonomy, with the genuine work of art serving no master but its own internal requirements, one such requirement of the visual work of art is that it exists to be beheld, it comes into being and exists for some audience. Beauty may serve no purpose, and may be defined by an internality as strict as the internal requirements of mathematics or morality, but unlike mathematics or morality, the artwork is defined by internal requirements which themselves include a relation to some beholder. And the interplay between anti-theatrical and formalist motivations shows how this inclusion threatens to compromise the very idea of aesthetic autonomy, as if aesthetic autonomy and independence themselves included a fatal dependency, and among art's internal requirements themselves was a necessary relation to something outside itself. 
